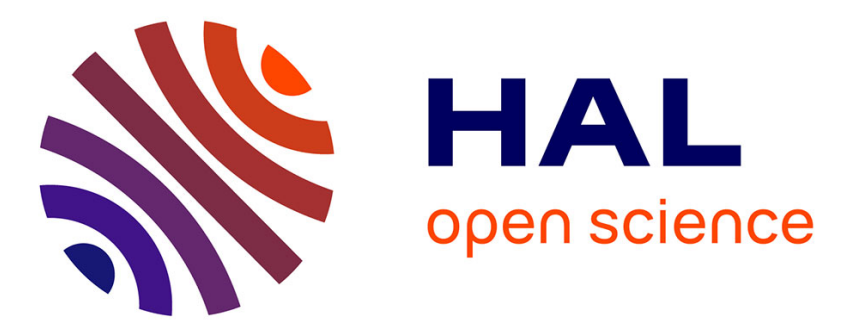

\title{
The Xe-SiO 2 System at Moderate Pressure and High Temperature
}

\author{
C. Crépisson, C. Sanloup, M. Blanchard, J. Hudspeth, K. Glazyrin, F. \\ Capitani
}

\section{- To cite this version:}

C. Crépisson, C. Sanloup, M. Blanchard, J. Hudspeth, K. Glazyrin, et al.. The Xe-SiO 2 System at Moderate Pressure and High Temperature. Geochemistry, Geophysics, Geosystems, 2019, 20 (2), pp.992-1003. 10.1029/2018GC007779 . hal-02107610v2

\section{HAL Id: hal-02107610 https://hal.science/hal-02107610v2}

Submitted on 23 Apr 2019

HAL is a multi-disciplinary open access archive for the deposit and dissemination of scientific research documents, whether they are published or not. The documents may come from teaching and research institutions in France or abroad, or from public or private research centers.
L'archive ouverte pluridisciplinaire HAL, est destinée au dépôt et à la diffusion de documents scientifiques de niveau recherche, publiés ou non, émanant des établissements d'enseignement et de recherche français ou étrangers, des laboratoires publics ou privés. 


\section{Geochemistry, Geophysics, Geosystems}

\author{
RESEARCH ARTICLE \\ 10.1029/2018GC007779 \\ Key Points: \\ - The $\mathrm{Xe}-\mathrm{SiO}_{2}$ system is studied by in \\ situ high-pressure and temperature \\ experiments and ab initio \\ calculations \\ - Xe is incorporated in quartz, and a \\ new $(\mathrm{Xe}, \mathrm{Si}) \mathrm{O}_{2}$ phase is identified \\ - These findings emphasize the need \\ to consider Xe storage in crust \\ minerals in the framework of the \\ "missing xenon" issue
}

Supporting Information:

- Supporting Information S1

Correspondence to:

C. Crépisson,

celinecrepisson@hotmail.fr

Citation:

Crépisson, C., Sanloup, C., Blanchard,

M., Hudspeth, J., Glazyrin, K., \&

Capitani, F. (2019). The $\mathrm{Xe}-\mathrm{SiO}_{2}$ system at moderate pressure and high

temperature. Geochemistry, Geophysics, Geosystems, 20, 992-1003. https://doi. org/10.1029/2018GC007779

Received 22 JUN 2018

Accepted 16 JAN 2019

Accepted article online 21 JAN 2019

Published online 15 FEB 2019

(c)2019. American Geophysical Union. All Rights Reserved.

\section{The $\mathrm{Xe}_{-} \mathrm{SiO}_{2}$ System at Moderate Pressure and High Temperature}

\author{
C. Crépisson', C. Sanloup ${ }^{1}$ (D, M. Blanchard ${ }^{2}$ (D), J. Hudspeth', K. Glazyrin ${ }^{3}$ (D) and F. Capitani ${ }^{4}$ \\ ${ }^{1}$ Sorbonne Université, CNRS, UMR 7193 - Institut des Sciences de la Terre de Paris (ISTeP), Paris, France, ${ }^{2}$ Géosciences \\ Environnement Toulouse (GET), Université de Toulouse, CNRS, IRD, UPS, Toulouse, France, ${ }^{3}$ Deutsches Electronen- \\ Synchrotron (DESY), Hamburg, Germany, ${ }^{4}$ Synchrotron SOLEIL, L'Orme des Merisiers, Saint-Aubin, Gif-sur-Yvette, \\ France
}

\begin{abstract}
Xenon (Xe), the heaviest of the stable noble gases, is missing by a factor of 20 relatively to other noble gases, when comparing the Earth's and Mars's atmospheres with chondrites. In this work, the possibility of Xe retention in quartz, a major mineral of the continental crust, is tested. The $\mathrm{Xe}_{-} \mathrm{SiO}_{2}$ system is investigated from 0.7 to $2.7 \mathrm{GPa}$ and up to $1900 \mathrm{~K}$, by in situ X-ray powder diffraction and infrared spectroscopy. Experimental data are complemented by ab initio calculations to retrieve Xe incorporation mechanisms. An excess of quartz unit cell volume up to $4.2 \%$ is observed, consistent with a Xe for $\mathrm{Si}$ substitution in the quartz structure. Xe has a linear oxygen environment composed of two $\mathrm{O}$ atoms located at 1.98-2.00 A from the Xe atom. Moreover, a new phase is evidenced above Xe melting curve at 0.8-1.0 GPa. The new $(\mathrm{Xe}, \mathrm{Si}) \mathrm{O}_{2}$ phase is orthorhombic and corresponds to an elongation of the quartz unit cell. In this phase, Xe substitutes for Si with a nearly planar oxygen environment composed of four $\mathrm{O}$ atoms located at 2.06-2.09 $\AA$ from the Xe atom. Xe incorporation in $\mathrm{SiO}_{2}$ proves to be significant, as previously shown for olivine. Xe incorporation is therefore expected to occur in the whole range of lithospheric silicate minerals. These findings emphasize the need to consider Xe incorporation in crust and upper mantle minerals as a process to store and fractionate xenon, in the framework of the "missing xenon" issue.
\end{abstract}

\section{Introduction}

\section{1. "Missing Xenon" and the "Xenon Paradox"}

$\mathrm{Xe}$ is commonly used to study the evolution of the atmosphere, based on its high volatility, relative chemical inertia, and its nine isotopes. However, Xe is missing in the atmospheres of Mars and of the Earth compared to chondrites, relative to other noble gases (Anders \& Owen, 1977). This phenomenon, known as the "missing Xe" issue, is associated with a deficit in light Xe isotopes in terrestrial and Martian atmospheres (Krummenacher et al., 1962; Swindle, 2002, respectively), which cannot be explained by radioactive decay alone. Studies of Xe isotopic compositions of Archean rocks have shown that Xe has been fractionated throughout the Archean (e.g., Avice et al., 2017; Pujol et al., 2011). Fractionation of Xe could continue nowadays via subduction processes (Holland \& Ballentine, 2006).

Several hypotheses have been proposed to explain both the missing Xe and the depletion in Xe light isotopes. Early hydrodynamic escape from the atmosphere (Pepin, 1991) has been suggested although it cannot explain why noble gases, lighter than Xe, are not missing more than Xe.

Xe isotope fractionation throughout the Archean could be explained by the combination of high ultraviolet (UV) flux from the young Sun (Figure 1) and the presence of an organic haze in the early Earth's atmosphere (Hébrard \& Marty, 2014). High UV flux enhances Xe photoionization at the altitude of the organic haze, Xe being preferentially ionized compared to other noble gases due to its low ionization potential. Xe is thus preferentially trapped in the organic haze, compared to other noble gases, with adsorption process inducing Xe isotopic fractionation (Marrocchi \& Marty, 2013). However, there is so far no clue for the presence of an organic haze in early Mars's history, and it is unclear if the UV flux, decreasing far more rapidly than Xe isotope fractionation (Figure 1), could explain Xe isotope fractionation throughout the entire Archean eon.

Xe could be stored in the core based on theoretical calculations showing that Xe could be stable up to $0.8 \mathrm{~mol} \%$ in an iron core (Lee \& Steinle-Neumann, 2006). Xe/Fe (Ni) intermetallic compounds were predicted to be stable in the core (Zhu et al., 2014) and recently synthesized (Stavrou et al., 2017). However, 


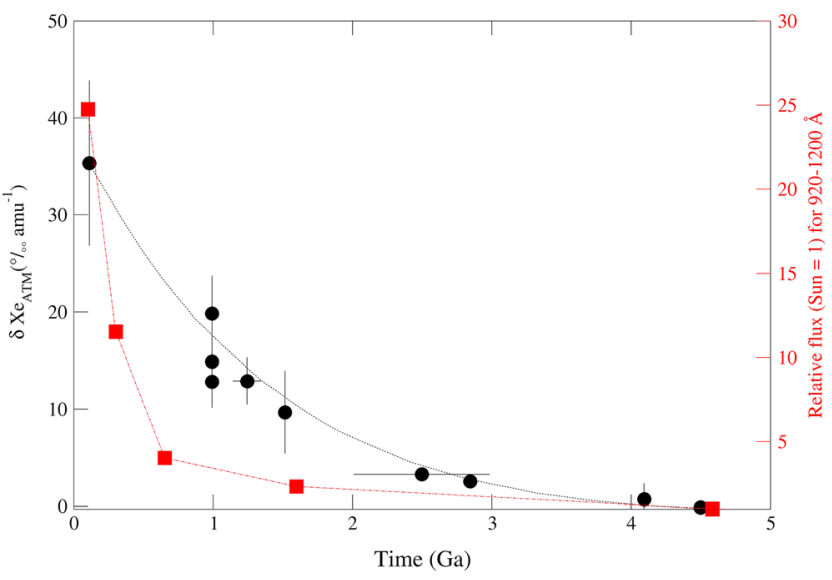

Figure 1. Ultraviolet solar flux and intense Xe isotope fractionation throughout the Earth history. Extreme ultraviolet solar flux shows rapid decrease compared to progressive Xe isotope fractionation. Plain black circles are data points showing Xe isotope fractionation (references in Hébrard \& Marty, 2014; recent measurement from Avice et al., 2017, has been added); dashed black line is average Xe isotope fractionation. Plain red squares are solar flux data points from Ribas et al. (2005), and dashed red line is a guide for the eyes.
Mars's and Earth's cores have different compositions and $P$ - $T$ conditions, which make Xe storage in the core unlikely to explain the missing Xe and the depletion in light Xe isotopes observed for both planets. Jephcoat (1998) proposed the formation of molten Xe clusters during Earth differentiation, which will be driven down to the core although scarcity of Xe makes the assumption hypothetical.

Storage of Xe in sediments has also been proposed due to high Xe content retrieved in siliceous sediments (Matsuda \& Matsubara, 1989), and shales (Bernatowicz et al., 1984), although volumes of sediments remain too small to explain the whole missing Xe.

Eventually, it has been proposed that Xe could be incorporated in mantle and continental crust minerals. Xe retention in crusts and mantles could thus be at stake for both planets. High Xe reactivity has been proved, with the synthesis of several Xe compounds (Grochala, 2007), among which Xe oxides at ambient conditions (Brock \& Schrobilgen, 2011), at high P-T conditions (Dewaele et al., 2016), and Xe-bearing perovskite (Britvin et al., 2015). Furthermore, Xe can be incorporated as a minor or trace element in $\mathrm{SiO}_{2}$ phases (Sanloup et al., 2002, 2005) and in olivine (Crépisson et al., 2018; Sanloup et al., 2011) at upper crustal and mantle conditions with up to 0.4 at\% Xe possibly stored in olivine. However, there are still few data regarding Xe incorporation in minerals, due to Xe high volatility, which requires in situ investigation at high pressure $(P)$ and temperature $(T)$.

\subsection{The $\mathrm{Xe}_{-} \mathrm{SiO}_{2}$ System}

Our previous X-ray study of the $\mathrm{Xe-SiO}$ system (Sanloup et al., 2005) showed an extension of the quartz stability field and the formation of platinum silicides inside the Pt capsule attesting the release of Si from quartz. These observations led to the hypothesis that Si reduction had been triggered through Xe for Si substitution reaction. Probert (2010) investigated Xe for Si and Xe for O substitutions, as well as Xe at interstitial site in $\alpha$ quartz by ab initio calculation using the density functional theory (DFT). All Xe incorporation mechanisms are stable at 0 and $2 \mathrm{GPa}$ (i.e., the two investigated $P$ ), although there is an energy barrier at $T=0 \mathrm{~K}$. Xe incorporation in fibrous silica, studied theoretically using post Hartree-Fock methods (Kalinowski et al., 2014), also occurs through substitution to Si surrounded by four oxygen atoms in fibrous silica, forming a stable compound well above room $T$.

In the present study, Xe incorporation mechanisms in $\alpha$-quartz and $\beta$-quartz are investigated experimentally and theoretically from DFT calculations. Quartz was chosen as a major mineral of the continental crust. $P$ and $T$ conditions are relevant for the continental crust, with highest $P$ and $T$ conditions relevant for orogenic contexts, where continental crust can reach 80-km depth ( 2.2 GPa and $1473 \mathrm{~K}$ under the Tibetan plateau; Jiménez-Munt et al., 2008).

\section{Methods}

\subsection{X-Ray Diffraction}

Two sets of in situ X-ray diffraction experiments are used here. The first set (XRD1) was collected on $\mathrm{SiO}_{2}\left(\mathrm{SiO}_{2}\right.$ as cristoballite or as Herasil glass) plus $\mathrm{Xe}$ gas loaded in a $\mathrm{Pt}$ capsule using a Paris Edinburgh cell composed of a boron epoxy gasket, with a graphite heater and hBN as the capsule container. X-ray diffraction data were collected up to $1 \mathrm{GPa}$ and $1900 \mathrm{~K}$ at $71.68 \mathrm{keV}$ on beamline ID27 at the European Synchrotron Radiation Facility (see supporting information in Sanloup et al., 2005 for more experimental details). The second set (XRD2) was collected on Xe/Ar-bearing quartz, synthesized in a piston cylinder press at $3.5 \mathrm{GPa}$ and $1373 \mathrm{~K}$ for $24 \mathrm{hr}$. For this purpose silica powder was loaded with a gaseous Xe/Ar 1:1 mix in a Pt capsule following method from Boettcher et al. (1989). In situ Xray diffraction data were collected up to $2.7 \mathrm{GPa}$ and $900 \mathrm{~K}$ using resistive heating diamond anvil cells. Experiments were conducted on beamline P02.2 at Petra III synchrotron source using a $3 \times 8-\mu \mathrm{m}^{2}$ beam 
at $42.7 \mathrm{keV}$. $P$ was determined using unit cell volume of a Pt grain inserted on the verge of the sample chamber, and $T$ was read from a type-K thermocouple located near the diamond tip. During each measurement, the cell was oscillated from $-3^{\circ}$ to $+3^{\circ}$ to avoid intensity artifacts from potential preferential orientation. Image plates were integrated with Fit2D (Hammersley, 1997) or DIOPTAS (Prescher \& Prakapenka, 2015). Le Bail refinements of crystal cell parameters were performed with GSAS software (Larson \& von Dreele, 2000).

\subsection{Infrared Spectroscopy}

In situ infrared (IR) spectra were collected on the same Xe-/Ar-bearing quartz as used for XRD2, at 1.0(3) $\mathrm{GPa}$ and up to $773 \mathrm{~K}$ using resistive heating diamond anvil cells. Two chambers were drilled in a Re gasket, one was loaded with $\mathrm{KCl}$ used as a transparent background and the other with a thin compressed platelet of the sample and further filled with $\mathrm{KCl}$. Experiments were conducted on beamline SMIS at SOLEIL synchrotron. $P$ was determined using fluorescence of a ruby sphere located in the sample chamber, and $T$ was read from a type-K thermocouple located near the diamond tip. IR spectra were retrieved from 650 to $4,000 \mathrm{~cm}^{-1}$ with a resolution of $0.5 \mathrm{~cm}^{-1}$ and accumulation of 100 scans, repeated 4 times. A MCT (mercury cadmium telluride) detector, frequently cooled by liquid nitrogen, was used. The background used for subtraction was measured through $\mathrm{KCl}$ after each sample measurement. IR spectra were smoothed using Savitzki-Golay filter.

\subsection{Ab Initio Calculations}

All calculations were done within the DFT and using the generalized gradient approximation (GGA) with Perdew-Burke-Ernzerhof (PBE) pseudopotentials of Perdew et al. (1996), with the PWscf code of the Quantum espresso package http://www.quantum-espresso.org/; Giannozzi et al., 2009). The same norm-conserving pseudopotentials (Troullier \& Martins, 1991) as in Crépisson et al. (2018) are used. Electronic wave functions (charge density) are expanded up to an energy cutoff of 80 (480) Ry. For the new $(\mathrm{Xe}, \mathrm{Si}) \mathrm{O}_{2}$ phase, electronic k-points sampling use a $2 \times 4 \times 4$ centered grid for the unit cell and a $2 \times 1 \times 1$ centered grid for the $1 \times 3 \times 3$ supercell. For $\alpha$-quartz unit cell, electronic k-points sampling uses a $2 \times 2 \times 2$ centered grid, while for the $2 \times 2 \times 2$ and $3 \times 3 \times 3$ supercells, calculations are restricted to the center of the Brillouin zone. These computational parameters allow the total energy to be converged within $1 \mathrm{mRy}$ per atom. For all investigated systems, the charge of the simulation cell is neutral, and spin-polarized calculations were tested, obtaining zero magnetic moments. Equilibrium structures are obtained after full relaxation of atomic positions and cell parameters until convergence of forces on atoms to less than $10^{-4}$ Ry per atomic unit. Born effective charges are obtained within the approach of Baroni et al. (2001). Born effective charges $\left(Z^{\mathrm{eff}}\right)$ are used to evaluate atomic charges as discussed by Ghosez et al. (1998). Following the same procedure as Balan et al. (2011), vibrational modes and corresponding IR absorption spectra were calculated from the dynamical matrix.

\section{Results and Discussion}

\subsection{Increase of Unit Cell Volume in the Presence of Xe}

As reported for olivine (Crépisson et al., 2018; Sanloup et al., 2011), the unit cell volume of quartz is systematically larger by up to $4.2 \%$, in the presence of $\mathrm{Xe}$, than the volume predicted by the equations of state of plain quartz based on in situ X-ray diffraction data from both XRD1 and XRD2 data sets (Table 1). The presence of Ar is unlikely to affect the unit cell volume of quartz as Ar is classically used as a $P$-transmitting medium. For $\alpha$-quartz, the excess volume presents a minimum at $468-565 \mathrm{~K}$, which is the Xe melting point at the $P$ of the experiment, possibly indicating a different Xe environment in $\alpha$-quartz below and above Xe melting point. For $\beta$-quartz, data were all collected above Xe melting point. It is not possible to evaluate cell distortions as there is no available thermal equation of state for cell parameters of quartz at our $P$ - $T$ conditions. For $\alpha$-quartz, predicted volumes are calculated with second-order Birch Murnaghan equation of state using parameters from Wang et al. (2015) and for $\beta$-quartz, from first-order thermal Birch Murnaghan equation of state, with $K_{T}$ obtained from linear interpolation of data from Dorogokupets (1995), thermal expansion from Bourova and Pascal (1998), and volume at $0 \mathrm{GPa}$ and $848 \mathrm{~K}$ from Kihara (1990).

To theoretically determine Xe incorporation mechanism in quartz, two supercells were built: $2 \times 2 \times 2$ and $3 \times 3 \times 3$ (relative to the unit cell of $\alpha$-quartz, i.e., nine atoms) and corresponding, respectively, to 1.4 at\% Xe 
Table 1

Experimental Quartz Cell Parameters and Volume Compared to Predicted Volume for Plain Quartz

\begin{tabular}{|c|c|c|c|c|c|c|}
\hline$P(\mathrm{GPa})$ & $T(\mathrm{~K})$ & Cell parameters $a, c(\AA)$ & Observed $\mathrm{V}\left(\AA^{3}\right)$ & Predicted V $\left(\AA^{3}\right)$ & Excess V(\%) & Phase \\
\hline \multirow[t]{2}{*}{2.65} & 298 & $4.860(1)$ & $110.00(4)$ & 106.56 & 3.1 & $\alpha$-quartz \\
\hline & & $5.378(3)$ & & & & \\
\hline \multirow[t]{2}{*}{2.05} & 371 & $4.873(1)$ & $110.58(4)$ & 108.03 & 2.3 & $\alpha$-quartz \\
\hline & & $5.378(3)$ & & & & \\
\hline \multirow[t]{2}{*}{1.26} & 468 & $4.893(1)$ & $111.51(3)$ & 110.23 & 1.1 & $\alpha$-quartz \\
\hline & & $5.378(3)$ & & & & \\
\hline \multirow[t]{2}{*}{1.2} & 565 & $4.900(1)$ & $112.12(3)$ & 110.72 & 1.2 & $\alpha$-quartz \\
\hline & & $5.392(2)$ & & & & \\
\hline \multirow[t]{2}{*}{1.62} & 685 & $4.910(1)$ & $112.51(3)$ & 109.97 & 2.3 & $\alpha$-quartz \\
\hline & & $5.390(2)$ & & & & \\
\hline \multirow[t]{2}{*}{1.93} & 771 & $4.912(1)$ & $112.73(3)$ & 109.39 & 3 & $\alpha$-quartz \\
\hline & & $5.394(2)$ & & & & \\
\hline \multirow[t]{2}{*}{2.55} & 873 & $4.918(1)$ & $112.80(3)$ & 108.04 & 4.2 & $\alpha$-quartz \\
\hline & & $5.384(3)$ & & & & \\
\hline \multirow[t]{2}{*}{1.01} & 1591 & $4.976(2)$ & $117.06(4)$ & 115.94 & 1.0 & $\beta$-quartz \\
\hline & & $5.459(4)$ & & & & \\
\hline \multirow[t]{2}{*}{1.03} & 1581 & $4.977(2)$ & $116.44(3)$ & 115.95 & 0.4 & $\beta$-quartz \\
\hline & & $5.434(3)$ & & & & \\
\hline \multirow[t]{2}{*}{0.96} & 1651 & $4.977(2)$ & $116.59(4)$ & 115.74 & 0.7 & $\beta$-quartz \\
\hline & & $5.435(4)$ & & & & \\
\hline \multirow[t]{2}{*}{0.95} & 1429 & $4.974(9)$ & $118.22(3)$ & 116.46 & 1.5 & $\beta$-quartz \\
\hline & & $5.517(2)$ & & & & \\
\hline \multirow[t]{2}{*}{0.85} & 1520 & $4.981(4)$ & $116.55(1)$ & 116.41 & 0.1 & $\beta$-quartz \\
\hline & & $5.425(7)$ & & & & \\
\hline
\end{tabular}

Note. Measurements on $\alpha$-quartz are from XRD2 data set and those on $\beta$-quartz from XRD1 data set. For data on $\alpha$ quartz, errors on $P$ and $T$ are $0.2 \mathrm{GPa}$ and $50 \mathrm{~K}$, and error on predicted volume is $\pm 0.5 \AA^{3}$. For $\beta$-quartz, errors on $P$ and $T$ are $0.3 \mathrm{GPa}$ and $50 \mathrm{~K}$, and error on predicted volume is $\pm 0.4 \AA^{3}$. Uncertainty on the last digit is given in brackets.

and 0.41 at\% Xe. Xe for $\mathrm{Si}, \mathrm{Xe}$ for $\mathrm{O}$ substitutions $\left(\mathrm{Xe}_{\mathrm{Si}}, \mathrm{Xe}_{\mathrm{O}}\right)$, and interstitial $\mathrm{Xe}\left(\mathrm{Xe}_{\mathrm{I}}\right)$ were investigated. Structures were fully relaxed at $0,1.2$, and $2.65 \mathrm{GPa}$. Relaxed configurations are similar at all $P$ and Xe contents and comparable to results from Probert (2010).

In $\mathrm{Xe}_{\mathrm{Si}}$ configuration, Xe is located in a quasilinear environment, surrounded by two $\mathrm{O}$ atoms at $1.98-2.00 \AA$ (i.e., within the sum of covalent radii that Xe forms with $\mathrm{O}, \sim 2 \AA$ ) while the next two $\mathrm{O}$ atoms, not located in the same plane as the two closest ones, are at 2.27-2.28 $\AA$ (Figure $2 \mathrm{a}) . Z^{\text {eff }}$ for Xe in $\mathrm{Xe}_{\mathrm{Si}}(+2.8)$ is smaller than for $\mathrm{Si}(+3.4)$ in pure $\alpha$-quartz (Table S1 in the supporting information), which is counterbalanced by slightly less negative $Z^{\text {eff }}$ for the four closest $\mathrm{O}$ atoms (Figure $2 \mathrm{a}$ and Table $\mathrm{S} 1$ ). In $\mathrm{Xe}_{\mathrm{O}}$ configuration, the closest Xe neighbor is $\mathrm{Si}$ atom at 2.5(1) $\AA$ (i.e., within the sum of covalent radii that Xe forms with $\mathrm{Si}$, $\sim 2.5 \AA$ ). $Z^{\text {eff }}$ for Xe in $\mathrm{Xe}_{\mathrm{O}}(+0.54)$ significantly differs from that for $\mathrm{O}(-1.7)$ in pure $\alpha$-quartz (Table S1), which is counterbalanced by smaller $Z^{\text {eff }}$ for the two closest $\mathrm{Si}$ and more negative $Z^{\text {eff }}$ for the three surrounding $\mathrm{O}$ compared to that for $\mathrm{Si}$ and $\mathrm{O}$ in pure $\alpha$-quartz (Figure $2 \mathrm{~b}$ and Table $\mathrm{S} 1$ ). In $\mathrm{Xe}_{\mathrm{I}}$ configuration, we find no atoms within the sum of covalent radii that Xe forms with $\mathrm{O}$ or Si. Xe introduces a slight $Z^{\text {eff }}$ excess (+0.13), counterbalanced by less negative $Z^{\text {eff }}$ for the four closest $\mathrm{O}$ compared to pure $\alpha$-quartz (Figure 2c and Table S1). It must be noted that $Z^{\text {eff }}$ for Xe dramatically varies as a function of the incorporation mechanism.

Occurrence of $\mathrm{Si}$ and $\mathrm{O}$ vacancies in quartz samples is suggested by water point defects (Cordier \& Dounkhan, 1991). Probert (2010) points out that energy formation of Si vacancy is higher than the one for $\mathrm{O}$ vacancy, especially in $\mathrm{SiO}_{2}$ environment, as expected in the Earth. Nevertheless, given the very low Xe content expected inside the Earth (approximately parts per billion), there might be anyhow enough $\mathrm{Si}$ vacancies to accommodate Xe.

We therefore define formation energies for the different Xe incorporation mechanisms from a vacancybearing quartz 
(a)
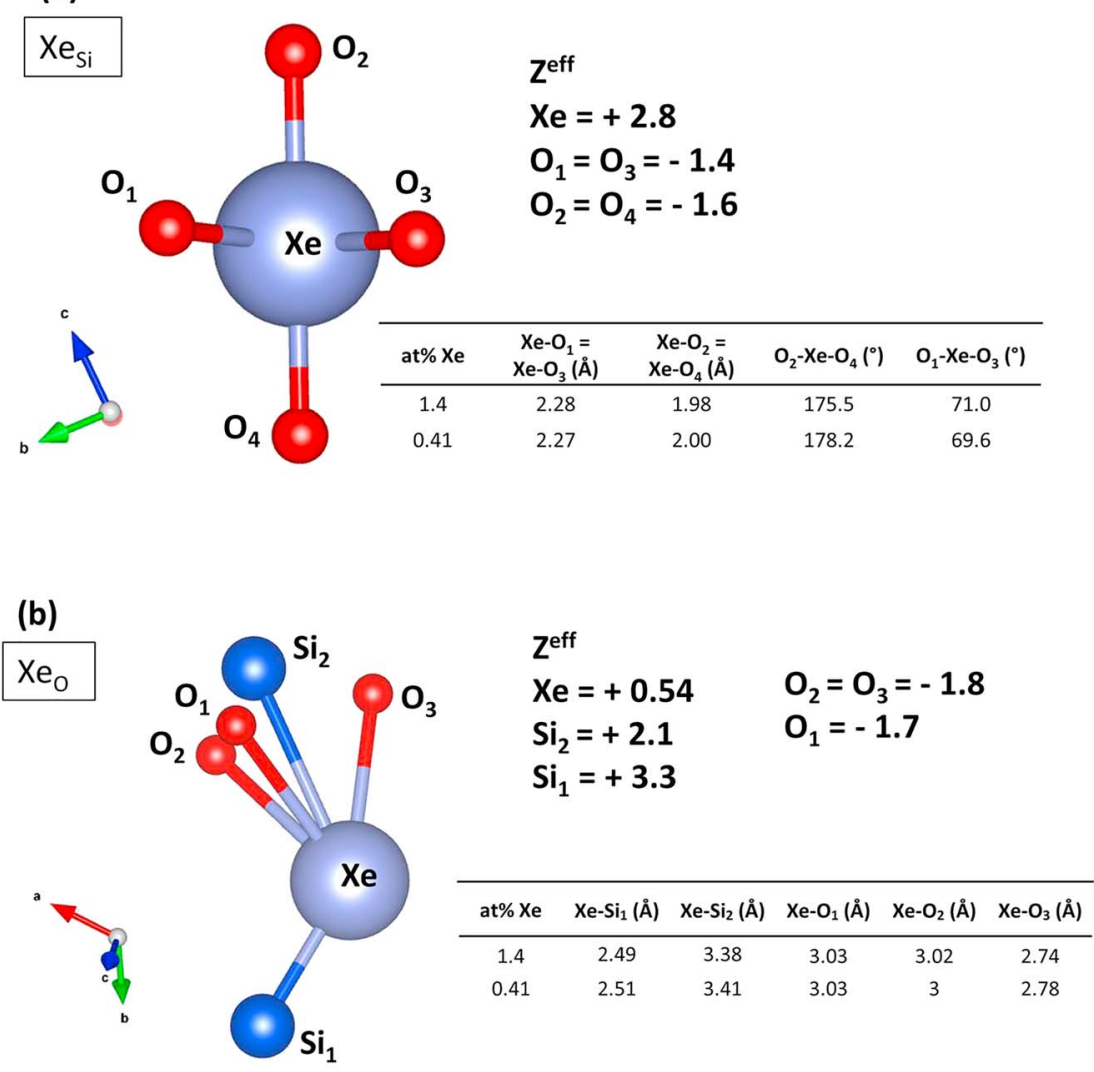

(c)

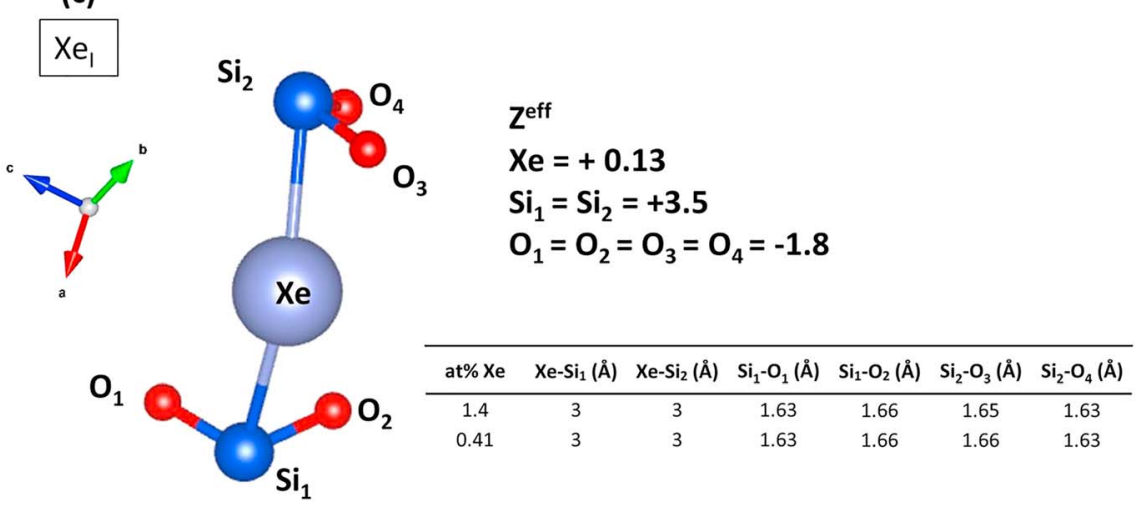

Figure 2. Local structural and electronic environment of Xe for the three investigated incorporation mechanisms (a: $\mathrm{Xe}_{\mathrm{Si}}$, $\left.\mathrm{b}: \mathrm{Xe}_{\mathrm{O}}, \mathrm{c}: \mathrm{Xe}_{\mathrm{I}}\right)$. Configurations are similar for all investigated Xe contents, and P. Atomic charges $\left(Z^{\mathrm{eff}}\right)$ were evaluated at $0 \mathrm{GPa}$ for 1.38 at\% Xe while bond lengths are given for both Xe contents. Si, O, and Xe are blue, red, and light blue ball, respectively.

$$
\begin{gathered}
\Delta E\left(\mathrm{Xe}_{\mathrm{Si}}\right)=E\left(\mathrm{Xe}_{\mathrm{Si}}\right)-E_{\mathrm{Xe}}-E_{\mathrm{Qz}-\mathrm{Si}} \\
\Delta E\left(\mathrm{Xe}_{\mathrm{O}}\right)=E\left(\mathrm{Xe}_{\mathrm{O}}\right)-E_{\mathrm{Xe}}-E_{\mathrm{Qz}-\mathrm{O}} \\
\Delta E\left(\mathrm{Xe}_{\mathrm{I}}\right)=E\left(\mathrm{Xe}_{\mathrm{I}}\right)-E_{\mathrm{Xe}}-E_{\mathrm{Qz}}
\end{gathered}
$$

where $E\left(\mathrm{Xe}_{\mathrm{Si}}\right), E\left(\mathrm{Xe}_{\mathrm{O}}\right)$ and $E\left(\mathrm{Xe}_{\mathrm{I}}\right)$ are the calculated energies for the cell used to simulate the different types of incorporation mechanisms $\left(\mathrm{Xe}_{\mathrm{Si}}, \mathrm{Xe}_{\mathrm{O}}\right.$, and $\left.\mathrm{Xe}_{\mathrm{I}}\right) \cdot E_{\mathrm{Xe}}$ is the energy of an isolated Xe atom. $E_{\mathrm{Qz}-\mathrm{Si}}$ and $E_{\mathrm{Qz}-\mathrm{O}}$ are the energies of the quartz cell with one neutral $\mathrm{Si}$ or $\mathrm{O}$ vacancy (the atomic structure was fully relaxed) 
Table 2

Calculated Energy Formation $\Delta E$ as Defined in the Text, for Xe-Doped Quartz (for 0.41 at\% Xe) for the Three Investigated Xe Incorporation Mechanisms

\begin{tabular}{lccc}
\hline$P(\mathrm{GPa})$ & $\Delta E\left(X e_{S i}\right)(\mathrm{eV})$ & $\Delta E\left(X e_{S i}\right)(\mathrm{eV})$ & $\Delta E\left(X e_{S i}\right)(\mathrm{eV})$ \\
\hline 0 & 1.0 & 4.9 & 4.8 \\
1.2 & 0.9 & 4.9 & 4.6 \\
2.65 & 0.9 & 4.6 & 4.6 \\
\hline
\end{tabular}

and $E_{\mathrm{Qz}}$ is the energy of a pure quartz cell. We report calculated $\Delta E$ values at $0,1.2$, and $2.65 \mathrm{GPa}$, for models corresponding to the lowest vacancy (and $\mathrm{Xe}$ ) concentration, that is, for the $3 \times 3 \times 3$ quartz supercell (Table 2). Results are consistent with those of Probert (2010): at $0 \mathrm{GPa}$ we calculated $\Delta E\left(\mathrm{Xe}_{\mathrm{Si}}\right)=1.0 \mathrm{eV}, \Delta E\left(\mathrm{Xe}_{\mathrm{O}}\right)=4.9 \mathrm{eV}$, and $\Delta E\left(\mathrm{Xe}_{\mathrm{I}}\right)=4.8 \mathrm{eV}$ against, respectively, $1.83,5.24$, and $5.24 \mathrm{eV}$ for Probert (2010). At all investigated pressures, $\Delta E$ is 4 to 5 times smaller for Xe incorporation in the Si vacancy $\left(\mathrm{Xe}_{\mathrm{Si}}\right)$ compared to interstitial $\left(\mathrm{Xe}_{\mathrm{I}}\right)$ and $\mathrm{O}$ vacancy $\left(\mathrm{Xe}_{\mathrm{O}}\right)$ incorporations, and as such, $\left(\mathrm{Xe}_{\mathrm{Si}}\right)$ is the likeliest incorporation mechanism.

For $0.41 \mathrm{at} \% \mathrm{Xe}$, at $0 \mathrm{GPa}$, an increase of unit cell volume, compared both to the bulk and to the vacancybearing quartz, is observed in the presence of Xe for all incorporation mechanisms (Tables 3 and S2) at the exception of $\mathrm{Xe}_{\mathrm{Si}}$ relative to the vacancy-bearing quartz, when a volume decrease of $-0.3 \%$ is observed. These results present significant discrepancies with Probert (2010) who calculated a decrease of volume for both $\mathrm{Xe}_{\mathrm{Si}}$ and $\mathrm{Xe}_{\mathrm{I}}$ relative to the bulk and for $\mathrm{Xe}_{\mathrm{Si}}$ an increase of volume relative to the vacancy-bearing quartz. At $2.65 \mathrm{GPa}$ we calculated an excess volume for all mechanisms relative both to bulk and vacancy-bearing quartz $\left(+0.6 \%\right.$ for $\mathrm{Xe}_{\mathrm{Si}}$, about $+1.5 \%$ for $\mathrm{Xe}_{\mathrm{O}}$, and $+2.2 \%$ for $\left.\mathrm{Xe}_{\mathrm{I}}\right)$. $\mathrm{These}$ results are in agreement with Probert (2010) who calculated a volume increase of $+0.42 \%$ for $\mathrm{Xe}_{\mathrm{Si}}$, $+1.87 \%$ for $\mathrm{Xe}_{\mathrm{O}}$, and $+1.7 \%$ for $\mathrm{Xe}_{\mathrm{I}}$ relative to the bulk, at $2 \mathrm{GPa}$. The significantly smallest excess volume is obtained in the case of Xe for Si substitution, with even a decrease at $0 \mathrm{GPa}$ and for 0.41 at\% Xe. In line with our previous study on Xe-bearing olivine (Crépisson et al., 2018), this small excess volume and the formation energies suggest that Xe for $\mathrm{Si}$ substitution is the likeliest Xe incorporation mechanism in quartz.

The $\alpha$-quartz and $\beta$-quartz structures are both hexagonal with same site multiplicities and only differ by minor variations of bond lengths and angles (Kihara, 1990). Due to structural similarity, results from ab initio calculations on Xe incorporation at $0 \mathrm{~K}$ are thus expected to be similar for both phases, with Xe for Si substitution being the likeliest Xe incorporation mechanism.

Xe substitution to Si did not result in the formation of a pure Si phase as none was observed in the X-ray diffraction data. Indeed, while Xe was initially loaded as a gas and could initially diffuse throughout the sample,

Table 3

Calculated Excess Volume (V) Relatively to (r.t.) Pure $\alpha$-Quartz (“r.t. bulk") or Vacancy-Bearing Quartz ("r.t. vacancy"), for Xe-Doped Quartz for the Three Investigated Xe Incorporation Mechanisms

\begin{tabular}{llccc}
\hline Xe incorporation mechanism & $P(\mathrm{GPa})$ & Xe content (at\%) & Excess V (\% r.t. bulk) & $\begin{array}{c}\text { Excess V } \\
\text { (\% r.t. vacancy) }\end{array}$ \\
\hline $\mathrm{Xe}_{\mathrm{Si}}$ & 0 & 1.4 & 1.6 & 2.3 \\
& 0 & 0.41 & 0.4 & -0.3 \\
& 1.2 & 1.4 & 1.8 & 1.0 \\
& 1.2 & 0.41 & 0.6 & 0.4 \\
& 2.65 & 1.4 & 1.9 & 2.1 \\
$\mathrm{Xe}_{\mathrm{O}}$ & 2.65 & 0.41 & 0.6 & 0.6 \\
& 0 & 1.4 & 4.2 & 5.4 \\
& 0 & 0.41 & 1.5 & 1.8 \\
& 1.2 & 1.4 & 4.1 & 5.1 \\
& 1.2 & 0.41 & 1.5 & 1.8 \\
$\mathrm{Xe}_{\mathrm{I}}$ & 2.65 & 1.4 & 4.2 & 5.1 \\
& 2.65 & 0.41 & 1.4 & - \\
& 0 & 1.4 & 2.4 & - \\
& 0 & 0.41 & 2.0 & - \\
\hline
\end{tabular}




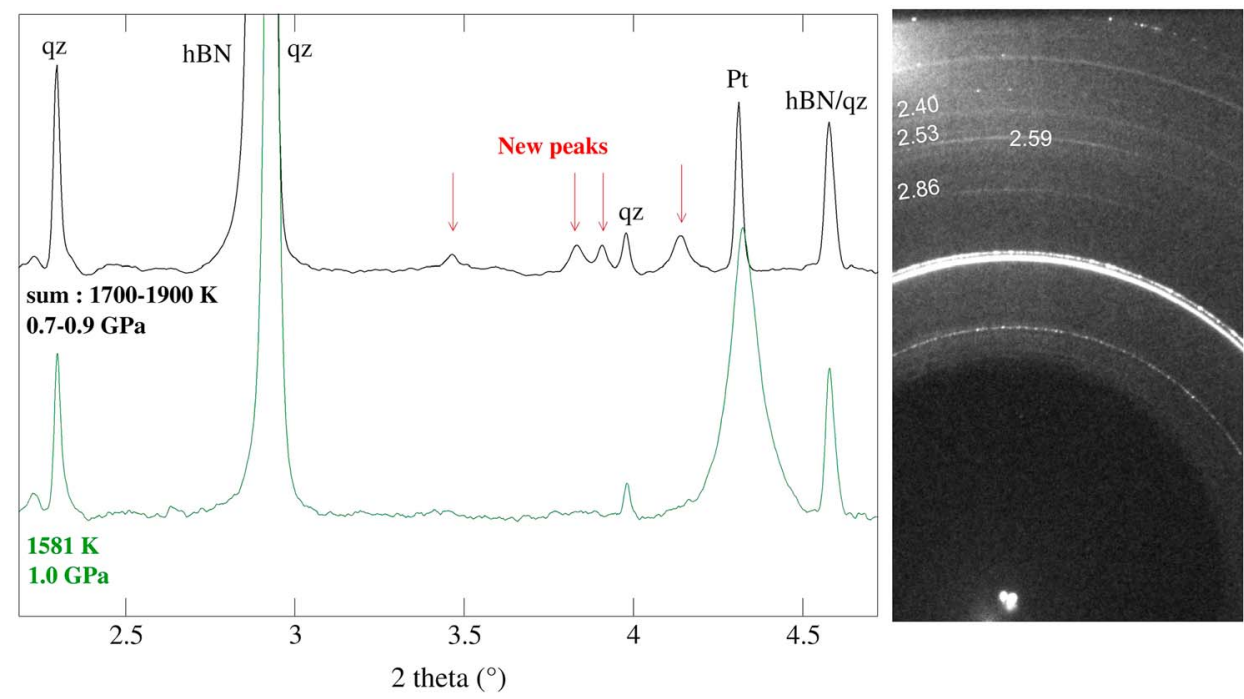

Figure 3. (left) X-ray diffraction pattern on $\mathrm{SiO}_{2}+\mathrm{Xe}$ at high $T(\geq 1700 \mathrm{~K}, \mathrm{XRD1}$ ). Summed X-ray diffraction pattern (black thick line) with four new peaks (red arrows) in addition to other $\beta$-quartz peaks and hBN or platinum (Pt.) peaks from the cell assembly, also visible at low $T$, (green line). (right) Image plate on $\mathrm{SiO}_{2}+\mathrm{Xe}$ at $0.8 \mathrm{GPa}$ and $1814 \mathrm{~K}$ with new interplanar distances. Numbers $(\AA)$ are interplanar distances corresponding to the four new continuous rings. The very bright ring corresponds to the (002) hBN peak.

the very slow diffusion rate of $\mathrm{Si}(\approx 0.2$ to $2 \mathrm{~nm}$ in $24 \mathrm{hr}$; Béjina \& Jaoul, 1996) prevented the formation of pure Si phase over the timescale of the experiments.

\subsection{A New (Xe,Si) $\mathrm{O}_{2}$ Phase at High Temperature}

\subsubsection{X-ray Diffraction Data}

In addition to $\beta$-quartz diffraction peaks, four new peaks appeared above $1700 \mathrm{~K}$ at $0.8(3) \mathrm{GPa}$ for XRD1 data set, for both cristobalite and $\mathrm{SiO}_{2}$ glass used as starting material, at interplanar distances of 2.86, 2.59, 2.53, and $2.40 \AA$ (Figure 3). These four new peaks correspond to continuous rings on the image plate (Figure 3) and cannot be attributed to any high- $T$ silica phase nor to potential contamination from the Pt capsule, such as $\mathrm{Pt}_{3} \mathrm{Si}$ observed in Sanloup et al. (2005) albeit at higher $P(P>4 \mathrm{GPa})$. Appearance of these four new peaks, in a very narrow interval of interplanar distances $(0.5 \AA)$, therefore attests the modification of the $\beta$-quartz structure in the presence of Xe, leading to the formation of a new phase. To maximize the signal-to-noise ratio in the area of the new peaks, six X-ray diffraction patterns recorded at similar $P-T$ conditions were summed.

The peaks observed in the summed pattern were indexed using DICVOL, a powder diffraction indexing software (Boultif \& Louër, 1991; Table S3). The solution of highest symmetry gives an average $2 \theta$ difference for indexed lines of $0.0018^{\circ}$. The solution is an orthorhombic cell with $a=8.66(1) \AA, b=5.45(1) \AA$, and $c=5.06(1) \AA$. This orthorhombic structure can be obtained by elongating $\beta$-quartz hexagonal unit cell $\left(a \approx 4.98 \AA\right.$ and $c \approx 5.45 \AA$ ) along the $b$ axis and by defining new axes $a^{\prime}, b^{\prime}$, and $c^{\prime}$ so that

Table 4

Crystallographic Structure Found by Elongation of $\beta$-Quartz in the P 222 Space Group

\begin{tabular}{lccccc}
\hline $\mathrm{SiO}_{2}$ & Atom & $x$ & $y$ & $Z$ & Wyckoff position \\
\hline $\mathrm{P} 222$ & $\mathrm{Si}$ & 0 & $1 / 2$ & 0 & $1 \mathrm{c}$ \\
Orthorhombic & $\mathrm{Si}$ & $1 / 4$ & $1 / 6$ & $1 / 4$ & $4 \mathrm{u}$ \\
$a=8.66(1) \AA$ & $\mathrm{Si}$ & $1 / 2$ & $1 / 2$ & $1 / 2$ & $1 \mathrm{~h}$ \\
$b=5.45(1) \AA$ & $\mathrm{O}$ & 0.10 & $2 / 3$ & 0.81 & $4 \mathrm{u}$ \\
$c=5.06(1) \AA$ & $\mathrm{O}$ & 0.60 & $1 / 3$ & 0.69 & $4 \mathrm{u}$ \\
& $\mathrm{O}$ & 0.71 & 0 & 0 & $2 \mathrm{i}$ \\
& $\mathrm{O}$ & 0.79 & 0 & $1 / 2$ & $2 \mathrm{j}$ \\
\hline
\end{tabular}

$$
\begin{gathered}
a^{\prime}=a+2 b \\
b^{\prime}=c \\
c^{\prime}=a
\end{gathered}
$$

These relations give $a^{\prime}=8.64 \AA, b^{\prime}=5.43 \AA$, and $c^{\prime}=5.00 \AA$, that is, close to the cell parameters obtained with DICVOL. The orthorhombic structure is thus considered as the likeliest based on its highest symmetry (other solutions are monoclinic) and the possibility to convert the $\beta$ quartz hexagonal structure into the orthorhombic structure by elongation. Based on extinction rules, four possible orthorhombic space groups were identified: P 22 2, P 22 21, Pmm2, and Pmmm. For P 22 21, only one Wyckoff position is possible, hence discarding this space group. 
Table 5

Theoretical Cell Parameters, Volumes and Energies for Xe for Si Substitutions

\begin{tabular}{lccllcrc}
\hline Xe for Si substitutions & at\% Xe & $a(\AA)$ & $b(\AA)$ & $c(\AA)$ & $\mathrm{V}\left(\AA^{3}\right)$ & Excess V $(\%)$ & Final energy $(\mathrm{eV})$ \\
\hline $\mathrm{Xe}_{\mathrm{Si}(4 \mathrm{u})}$ & 5.56 & 8.75 & 6.03 & 4.80 & 252.94 & 6.07 & -6189.43 \\
$\mathrm{Xe}_{\mathrm{Si}(1 \mathrm{~h})} \mathrm{Xe}_{\mathrm{Si}(1 \mathrm{c})}$ & 5.56 & 9.41 & 6.06 & 4.77 & 271.92 & 14.03 & -6189.00 \\
$\mathrm{Xe}_{\mathrm{Si}(4 \mathrm{u})}$ & 0.62 & 8.74 & 5.58 & 5.00 & 243.84 & 2.25 & -53280.20 \\
$\mathrm{Xe}_{\mathrm{Si}(1 \mathrm{~h})} \mathrm{Xe}_{\mathrm{Si}(1 \mathrm{c})}$ & 0.62 & 8.93 & 5.49 & 5.12 & 251.01 & 5.26 & -53280.64 \\
$(\mathrm{Xe}, \mathrm{Si}) \mathrm{O}_{2}$ phase (exp.) & - & $8.66(1)$ & $5.45(1)$ & $5.06(1)$ & $239(1)$ & - & - \\
\hline
\end{tabular}

Note. Results at $0 \mathrm{GPa}$ for the three possible Wyckoff positions $(1 \mathrm{~h}, 1 \mathrm{c}$, and $4 \mathrm{u})$ compared with experimental observations (exp.).

There are $3 \mathrm{Si}$ and $6 \mathrm{O}$ atoms in one unit cell of $\beta$-quartz, and consequently, $6 \mathrm{Si}$ and $12 \mathrm{O}$ atoms are expected in the new orthorhombic cell. We use starting crystallographic structure from Kihara (1990) for $\beta$-quartz (at the highest available temperature, i.e., $1351 \mathrm{~K}$ ) and perform symmetry operations previously described, as well as a change of the origin $\left(O^{\prime}=O+1 / 2 a+1 / 2 c\right)$ to obtain the new atomic positions. Based on the multiplicity of Wyckoff positions, atomic positions can only be described in the P 222 space group (Table 4).

Xe incorporation occurs through Xe for Si substitution in olivine (Crépisson et al., 2018; Sanloup et al., 2011), and Xe retention in quartz was shown to release Si. Furthermore, the present ab initio calculations show that $\mathrm{Xe}$ for Si substitution is the likeliest Xe incorporation mechanism in quartz (3.1.). Therefore, we assume that Xe substitutes for Si in the new orthorhombic phase, Si being present on 1c, 1h, and $4 \mathrm{u}$ Wyckoff positions for the new orthorhombic phase (Table 4).
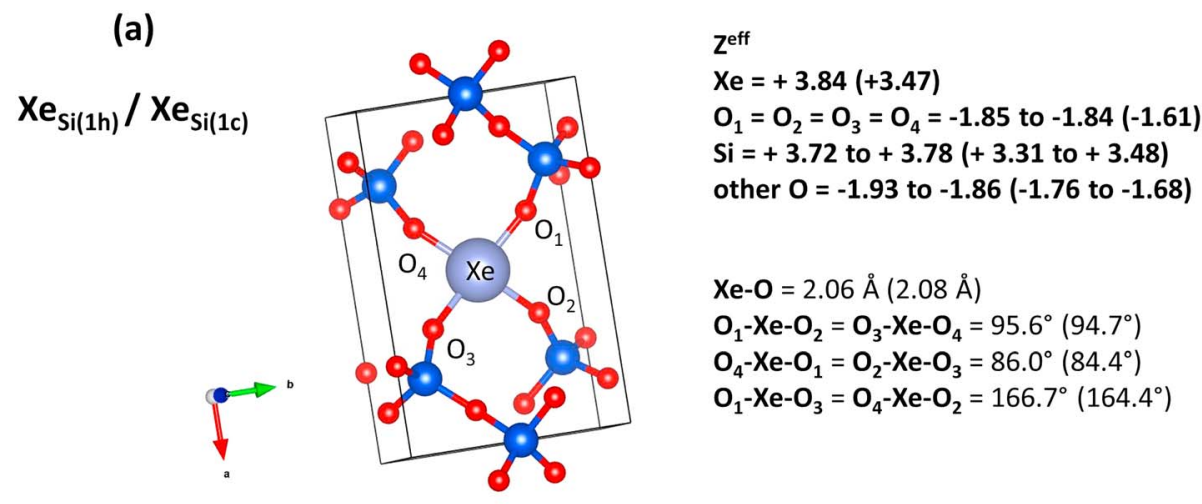

(b)

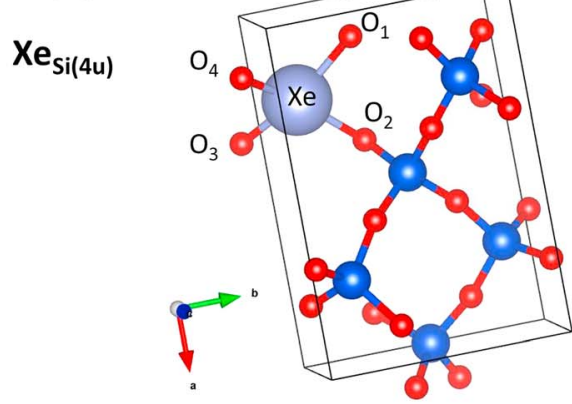

$Z^{\text {eff }}$

$\mathrm{Xe}=+3.45(+3.21)$

$\mathrm{O}_{1}=\mathrm{O}_{2}=\mathrm{O}_{3}=\mathrm{O}_{4}=-1.68(-1.50$ to -1.48$)$

$\mathrm{Si}=+3.64$ to $+3.75(+3.28$ to +3.66$)$

other $0=-1.99$ to $-1.75(-1.91$ to -1.64$)$

$\mathrm{Xe}-\mathrm{O}_{1}=\mathrm{Xe}-\mathrm{O}_{2}=2.07 \AA(2.09 \AA)$

$\mathrm{Xe}-\mathrm{O}_{3}=2.03 \AA$ (2.08 $\AA$ )

$\mathrm{Xe}-\mathrm{O}_{4}=2.03 \AA(2.09 \AA)$

$\mathbf{O}_{4}-\mathbf{X e}-\mathrm{O}_{1}=94.8^{\circ}\left(96.6^{\circ}\right)$

$\mathrm{O}_{3}-\mathrm{Xe}-\mathrm{O}_{2}=94.8^{\circ}\left(94.3^{\circ}\right)$

$\mathbf{O}_{1}-\mathbf{X e}-\mathbf{O}_{2}=85.8^{\circ}\left(89.1^{\circ}\right)$

$\mathbf{O}_{3}-\mathbf{X e}-\mathbf{O}_{4}=93.3^{\circ}\left(91.2^{\circ}\right)$

$\mathrm{O}_{1}-\mathrm{Xe}-\mathrm{O}_{3}=157.2^{\circ}\left(154.7^{\circ}\right)$

$\mathrm{O}_{2}-\mathrm{Xe}-\mathrm{O}_{4}=157.2^{\circ}\left(154.3^{\circ}\right)$

Figure 4. Relaxed structures of the new $(\mathrm{Xe}, \mathrm{Si}) \mathrm{O}_{2}$ phase at $0 \mathrm{GPa}$ with $\mathrm{Xe}$ in either $1 \mathrm{~h}, 1 \mathrm{c}(\mathrm{a})$ or $4 \mathrm{u}(\mathrm{b})$ site. Bond lengths angles and atomic charges $\left(Z^{\text {eff }}\right)$ are given for 5.56 at\% Xe and in brackets for 0.62 at\% Xe. Si, O, and Xe are blue, red, and light blue ball, respectively. 


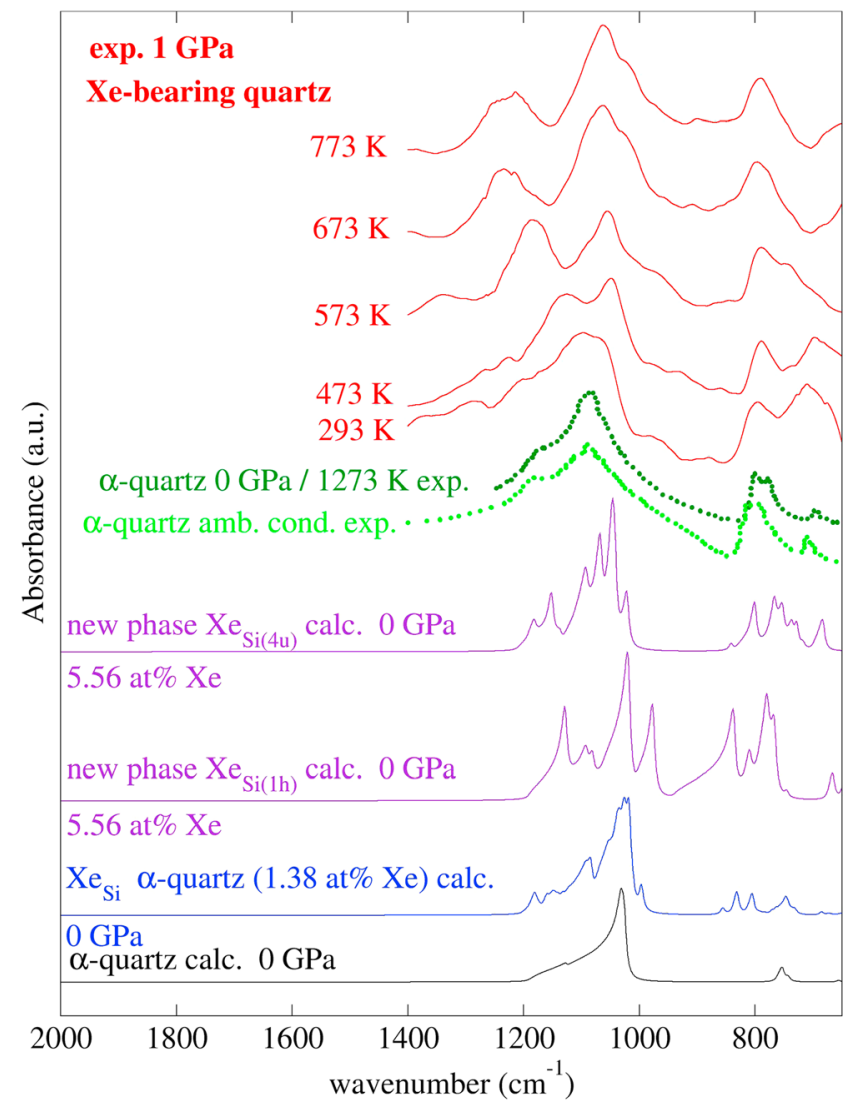

Figure 5. IR spectra for the $\mathrm{Xe}_{\mathrm{e}} \mathrm{SiO}_{2}$ system. Experimental (exp.) IR spectra (red) recorded at high $P$ - $T$ conditions compared with experimental spectra for $\alpha$-quartz (at $0 \mathrm{GPa}$ and $1273 \mathrm{~K}$ from Shoval et al., 1997, and at ambient conditions from Williams et al., 1993), calculated (calc.) spectra for $\alpha$-quartz and the new $(\mathrm{Xe}, \mathrm{Si}) \mathrm{O}_{2}$ phase.

The new $(\mathrm{Xe}, \mathrm{Si}) \mathrm{O}_{2}$ phase results from the elongation of the $\beta$-quartz, similar to the formation of wadsleyite-II $\left(\mathrm{Mg}_{1.71} \mathrm{Fe}_{0.177} \mathrm{Al}_{0.01} \mathrm{Si}_{0.967} \mathrm{H}_{0.332} \mathrm{O}_{4}\right)$ from wadsleyite $\left(\beta-\mathrm{Mg}_{2} \mathrm{SiO}_{4}\right)$ in the presence of water at $17.5 \mathrm{GPa}$ and $1673 \mathrm{~K}$ (Smyth \& Kawamoto, 1997). Wadsleyite-II has the same orthorhombic space group and the same $a$ and $c$ axes as wadsleyite, whereas its $b$ axis is 2.5 times longer. X-ray diffraction patterns of both minerals are very similar, apart from some slight differences in peak intensities and appearance of five new peaks for wadsleyite II (Smyth et al., 2005).

\subsubsection{Ab Initio Calculations}

Xe location and occupancy in the new $(\mathrm{Xe}, \mathrm{Si}) \mathrm{O}_{2}$ phase cannot be refined by Rietveld refinement due to the use of Sollers slits that affects peak intensity versus $2 \theta$. Instead, ab initio calculations were performed using elongated $\beta$-quartz as the starting structure (Table 4). Xe was substituted for $\mathrm{Si}$ on $1 \mathrm{~h}, 1 \mathrm{c}$, or $4 \mathrm{u}$ Wyckoff positions $\left(\mathrm{Xe}_{\mathrm{Si}(1 \mathrm{~h})}, \mathrm{Xe}_{\mathrm{Si}(1 \mathrm{c})}\right.$, or $\mathrm{Xe}_{\mathrm{Si}(4 \mathrm{u})}$, respectively). Structures were fully relaxed at $0 \mathrm{GPa}$ for one Xe atom per unit cell (i.e., 5.56 at\% Xe or $28.32 \mathrm{wt} \% \mathrm{Xe}$ ) and for a $1 \times 3 \times 3$ supercell (i.e., $0.62 \mathrm{at} \% \mathrm{Xe}$ or $5.92 \mathrm{wt} \% \mathrm{Xe}$ ). Indeed, $36.6 \mathrm{wt} \%$ Xe to $38.1 \mathrm{wt} \% \mathrm{Xe}$ were initially loaded in these experiments; thus, we test circa maximal Xe content and a lower Xe content. It was shown that only 0.4 at\% Xe can be incorporated in the olivine structure (Crépisson et al., 2018), and thus, only a part of the available Xe may have been incorporated in the new $(\mathrm{Xe}, \mathrm{Si}) \mathrm{O}_{2}$ phase.

$\mathrm{Xe}_{\mathrm{Si}(1 \mathrm{~h})}, \mathrm{Xe}_{\mathrm{Si}(1 \mathrm{c})}$ lead to similar structures, $1 \mathrm{~h}$ and $1 \mathrm{c}$ positions being equivalent by translation of the unit cell. For the three sites, final total energies are similar within $0.4 \mathrm{eV}$, and the most stable configuration depends on Xe content (Table 5). Calculated volume for Xe in $1 \mathrm{~h}$ or $1 \mathrm{c}$ sites is larger than for Xe in $4 \mathrm{u}$ site, and both are larger than experimentally determined volume. Keeping the same reasoning as before, we note that the volume increase related to the presence of Xe is smaller in the

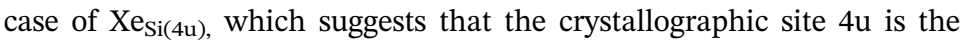
likeliest location.

Relaxed structures are shown in Figures $4 \mathrm{a}$ and $4 \mathrm{~b}$. Xe is surrounded by four $\mathrm{O}$ atoms in a quasi-planar configuration, for both $\mathrm{Xe}_{\mathrm{Si}(1 \mathrm{~h})}$ and $\mathrm{Xe}_{\mathrm{Si}(4 \mathrm{u})}$, with $\mathrm{Xe}-\mathrm{O}$ bond lengths equal to 2.02-2.09 $\AA$, that is, close to the sum of covalent radii of Xe and $\mathrm{O}(\sim 2 \AA)$. This result is similar to predicted mechanism of Xe incorporation in fibrous silica, where Xe substituted for Si with a planar local environment formed by four oxygen atoms and Xe-O bond lengths of $2.17 \AA$ (Kalinowski et al., 2014). However, this result differs from Xe incorporation in olivine: although Xe also substituted for Si with a quasi-planar local environment and Xe-O bonds lengths circa $2 \AA$ A, Xe was surrounded only by three O atoms in olivine (Crépisson et al., 2018).

For $\mathrm{Xe}_{\mathrm{Si}(1 \mathrm{~h})}$ or $\mathrm{Xe}_{\mathrm{Si}(1 \mathrm{c})} Z^{\mathrm{eff}}$ for Xe is larger than average for Si atoms located far from Xe. $Z^{\text {eff }}$ for the four surrounding $\mathrm{O}$ are also less negative than for O located far from Xe (Figure 4a). The general excess $Z^{\text {eff }}$ is likely

Table 6

IR Active Frequencies for $\alpha$-Quartz From Experiments (Exp.) and Calculations (Calc)

\begin{tabular}{lcccl}
\hline $\begin{array}{l}\text { Shoval et al. (1997), } \\
\text { exp. at 1273 K }\end{array}$ & $\begin{array}{c}\text { Williams et al. } \\
\text { (1993), exp. }\end{array}$ & This work calc. & $\begin{array}{c}\text { Méheut } \\
\text { (2008) calc. }\end{array}$ & $\begin{array}{l}\text { Mode } \\
\text { symmetry }\end{array}$ \\
\hline 1166 & 1170 & 1127 & 1128 & $\mathrm{E}$ \\
1084 & 1080 & 1031 & 1033 & $\mathrm{~A}_{2}$ \\
- & - & 1026 & 1028 & $\mathrm{E}$ \\
797 & 800 & 753 & 754 & $\mathrm{E}$ \\
778 & 780 & 742 & 745 & $\mathrm{~A}_{2}$ \\
694 & 696 & 656 & 657 & $\mathrm{E}$ \\
\hline
\end{tabular}


counterbalanced by the whole electric field of surrounding atoms. For Xe $\mathrm{Si}_{\mathrm{Si}(4)} Z^{\mathrm{eff}}$ for Xe is smaller than for Si atoms located far from Xe, which is counterbalanced by slightly less negative $Z^{\text {eff }}$ for the four surrounding $\mathrm{O}$, compared to that for $\mathrm{O}$ atoms located far from Xe (Figure $4 \mathrm{~b}$ ), similar to what is observed for $\mathrm{Xe}$ for $\mathrm{Si}$ substitution in $\alpha$-quartz (Figure 2a).

\subsubsection{Infrared Data}

In situ infrared spectrum recorded at 1.0(3) GPa and ambient $T$ compares well with that of $\alpha$-quartz at ambient conditions (Figure 5; Williams et al., 1993). Upon increasing $T$, above $473 \mathrm{~K}$, a progressive splitting of the $1,085-\mathrm{cm}^{-1}$ band related to asymmetric stretching vibrations of $\mathrm{SiO}_{4}$ tetrahedra (Williams et al., 1993) is observed (Figure 5). This is not expected for pure quartz, as IR quartz signal at $1273 \mathrm{~K}$ (Shoval et al., 1997) is similar to the one recorded at ambient conditions, except for a slight shift in frequency (Figure 5 and Table 6). Splitting must thus be related to Xe incorporation in quartz at $T=473 \mathrm{~K}$, that is, just above Xe melting point (Ferreira \& Lobo, 2008).

$\mathrm{Ab}$ initio calculations for pure $\alpha$-quartz at $0 \mathrm{GPa}$ are in agreement with experimental data from Williams et al. (1993) and Shoval et al. (1997; Table 6) apart from a global shift in frequency, common to DFT calculations. Our results also agree with theoretical calculations from Méheut (2008), who used similar computational techniques (Table 6).

IR signal was calculated for Xe for Si substitution in $\alpha$-quartz $\left(\mathrm{Xe}_{\mathrm{Si}}\right.$ ) for 1.38 at\% Xe (Figures 2a and 5). $\mathrm{Xe}_{\mathrm{Si}}$ in $\alpha$-quartz cannot explain the observed splitting of the main $1,085-\mathrm{cm}^{-1}$ band despite the calculated new contributions at $30-\mathrm{cm}^{-1}$ below and at $50-150 \mathrm{~cm}^{-1}$ above the main band, as those are too weak.

Instead, a phase transition could be at stake, as observed by X-ray diffraction (Figures 3, 4a, and 4b). To test this hypothesis, we calculated IR signal of the new $(\mathrm{Xe}, \mathrm{Si}) \mathrm{O}_{2}$ phase for 5.56 at $\% \mathrm{Xe}$, for $\mathrm{Xe}_{\mathrm{Si}(1 \mathrm{~h})}$ and $\mathrm{Xe}_{\mathrm{Si}(4 \mathrm{u})}$ configurations (Figures 4a, 4b, and 5). For both configurations a splitting of the main $1,085-\mathrm{cm}^{-1}$ band is observed: for $\mathrm{Xe}_{\mathrm{Si}(1 \mathrm{~h})}$ significant contributions appear at $50 \mathrm{~cm}^{-1}$ below and $120 \mathrm{~cm}^{-1}$ above the main band and for $\mathrm{Xe}_{\mathrm{Si}(4 \mathrm{u})}$ at $150 \mathrm{~cm}^{-1}$ above the main band (Figure 5). IR signal of $\mathrm{Xe} \mathrm{Si}_{\mathrm{Si}(4)}$ compares significantly better to the experimental IR spectra than that of $\mathrm{Xe}_{\mathrm{Si}(1 \mathrm{~h})}$ (Figure 5), and $\mathrm{Xe} \mathrm{e}_{\mathrm{Si}(4 \mathrm{u})}$ leads to a smaller volume increase than $\mathrm{Xe}_{\mathrm{Si}(1 \mathrm{~h})}$ (Table 5); thus, $\mathrm{Xe}_{\mathrm{Si}(4 \mathrm{u})}$ is the likeliest configuration for the new $(\mathrm{Xe}, \mathrm{Si}) \mathrm{O}_{2}$ phase. Transition to the new (Xe,Si) $\mathrm{O}_{2}$ phase from $\alpha$-quartz is not surprising due to the similarity of $\alpha$ - quartz and $\beta$-quartz structures. We note that phase transition observed by X-ray diffraction occurred at much higher $T$ (3.2.1) potentially controlled by diffusion of Xe which was initially loaded as a pure phase surrounding silica, in contrast to IR data experiment where the starting material was already Xe doped.

\section{Conclusions}

Xe retention in $\mathrm{SiO}_{2}$ at the conditions of the deep continental crust is elucidated. Xe substitutes to $\mathrm{Si}$ in quartz, as in olivine (Crépisson et al., 2018). In addition to Xe incorporation as point defects in quartz, for the first time a phase transition is observed in the presence of Xe at higher $T$. Occurrence of a phase transition indicates that $\mathrm{Xe}$ for $\mathrm{Si}$ substitution is increasingly enhanced above Xe melting curve, breaking the

Acknowledgments

We thank Lorenzo Paulatto for his help with calculations. Calculations were performed using MeSU servers at Sorbonne Université. We acknowledge Petra III at DESY, a member of the Helmholtz Association (HGF), for provision of synchrotron X-ray diffraction beam time at $\mathrm{P} 02.2$ beamline (Proposal I-2016062) and SOLEIL for provision of synchrotron radiation facilities at beamline SMIS (Proposal 20170085, in situ IR spectroscopy). Configurations obtained from relaxation of the three different Xe incorporation mechanisms in alphaquartz at all investigated pressures and Xe contents, IR data, and X-ray diffraction data newly collected for this study (XRD2 data set) are available at the hestia website (http://hestia.istep. upmc.fr:8080/sharing/VDl2iK3h9). quartz symmetry at a macroscopic scale, thus suggesting high $\mathrm{Xe}$ content in the new $(\mathrm{Xe}, \mathrm{Si}) \mathrm{O}_{2}$ phase.

Xe is incorporated in quartz at point defects bonding closely to two oxygens in a linear configuration, while in the new $(\mathrm{Xe}, \mathrm{Si}) \mathrm{O}_{2}$ phase $\mathrm{Xe}$ is bonded to four oxygens in a quasi-planar environment. In both cases $\mathrm{Xe}-\mathrm{O}$ bond lengths range from 1.98 to $2.09 \AA$, proving that Xe-O bonds are at least partly covalent.

Xe reactivity is thus widespread in lithospheric minerals, affecting at least quartz and olivine; quartz, the silicic end-member, being representative of the continental crust, while olivine, the magnesian end-member, is representative of the lithospheric mantle. Xe reactivity is therefore expected to be ubiquitous in the lithosphere and potentially at greater depths which remains to be investigated.

\section{References}

Anders, E., \& Owen, T. (1977). Mars and Earth: Origin and abundance of volatiles. Science, 198(4316), 453-465. https://doi.org/10.1126/ science.198.4316.453

Avice, G., Marty, B., \& Burgess, R. (2017). The origin and degassing history of the Earth's atmosphere revealed by Archean xenon. Nature Communications, 8 . https://doi.org/10.1038/ncomms 15455

Balan, E., Ingrin, J., Delattre, S., Kovács, I., \& Blanchard, M. (2011). Theoretical infrared spectrum of OH-defects in forsterite. European Journal of Mineralogy, 23, 285-292. 
Baroni, S., de Gironcoli, S., \& Dal Corso, A. (2001). Phonons and related properties of extended systems from density-functional perturbation theory. Reviews of Modern Physics, 73, 515-562.

Bernatowicz, T. J., Podosek, F. A., Honda, M., \& Kramer, F. E. (1984). The atmospheric inventory of xenon and noble gases in shales: The plastic bag experiment. Journal of Geophysical Research, 89(B6), 4597-4611. https://doi.org/10.1029/JB089iB06p04597

Béjina, F., \& Jaoul, O. (1996) Silicon self-diffusion in quartz and diopside measured by nuclear micro-analysis methods. Physics of the Earth and Planetary Interiors, 97, 145-162.

Boettcher, S. L., Guo, Q., \& Montana, A. (1989). A simple device for loading gases in high-pressure experiments. American Mineralogist, 74, 1383-1384.

Boultif, A., \& Louër, D. (1991). Indexing of powder diffraction patterns for low-symmetry lattices by the successive dichotomy method. Journal of Applied Crystallography, 987-993.

Bourova, E., \& Pascal, R. (1998). Quartz and cristobalite: High-temperature cell parameters and volumes of fusion. Geophysical Research Letters, 25(13), 2333-2336.

Britvin, S. N., Kashtanov, S. A., Krzhizhanovskaya, M. G., Gurinov, A. A., Glumov, O. V., Strekopytov, S., et al.. 2015. Perovskites with the framework-forming xenon. ANGEWANDTE CHEMIE INTERNATIONAL EDITION.

Brock, D. S., \& Schrobilgen, G. J. (2011). Synthesis of the missing oxide of xenon, XeO2, and its implications for Earth's missing xenon. Journal of the American Chemical Society, 133(16), 6265-6269. https://doi.org/10.1021/ja110618g

Cordier, P., \& Dounkhan, J. C. (1991). Water speciation in quartz: a near infrared study. American Mineralogist 76(3), 361-369.

Crépisson, C., Blanchard, M., Lazzeri, M., Balan, E., \& Sanloup, C. (2018). New constraints on Xe incorporation mechanisms in olivine from first-principles calculations. Geochimica et Cosmochimica Acta, 222, 146-155.

Dewaele, A., Worth, N., Pickard, C. J., Needs, R. J., Pascarelli, S., Mathon, O., et al. (2016). Synthesis and stability of xenon oxides Xe2O5 and $\mathrm{Xe} 3 \mathrm{O} 2$ under pressure. Nature Chemistry.

Dorogokupets, P. I. (1995). Equation of state for lambda transition in quartz. Journal of Geophysical Research, 100(B5), 8489-8499. https:// doi.org/10.1029/94JB02917

Ferreira, A. G. M., \& Lobo, L. Q. (2008). The fusion curves of xenon, krypton, and argon. The Journal of Chemical Thermodynamics, 40(4), 618-624. https://doi.org/10.1016/j.jct.2007.11.007

Ghosez, P., Michenaud, J.-P., \& Gonze, X. (1998). Dynamical atomic charges: The case of ABO3 compounds. Physical Review B, 58(10), 6224-6240. https://doi.org/10.1103/PhysRevB.58.6224

Giannozzi, P., Baroni, S., Bonini, N., Calandra, M., Car, R., Cavazzoni, C., et al. (2009). QUANTUM ESPRESSO: A modular and opensource software project for quantum simulations of materials. Journal of Physics: Condensed Matter, 21(39), 395,502-395,521.

Grochala, W. (2007). Atypical compounds of gases, which have been called 'noble'. Chemical Society Reviews, 36(10), 1632-1655. https:// doi.org/10.1039/b702109g

Hammersley, A. (1997). FIT2D: An introduction and overview. Technical Report No.ESRF97HA02, ESRF.

Hébrard, E., \& Marty, B. (2014). Coupled noble gas-hydrocarbon evolution of the early Earth atmosphere upon solar UV irradiation. Earth and Planetary Science Letters, 385, 40-48. https://doi.org/10.1016/j.epsl.2013.10.022

Holland, G., \& Ballentine, C. J. (2006). Seawater subduction controls the heavy noble gas composition of the mantle. Nature, 441, 186-191.

Jephcoat, A. P. (1998). Rare-gas solids in the Earth's deep interior. Nature, 393(6683), 355-358. https://doi.org/10.1038/30712

Jiménez-Munt, I., Fernàndez, M., Vergés, J., \& Platt, J. P. (2008). Lithosphere structure underneath the Tibetan Plateau inferred from elevation, gravity and geoid anomalies. Earth and Planetary Science Letters, 267, 276-289.

Kalinowski, J., Markku, R., \& Gerber, R. B. (2014). Chemically-bound xenon in fibrous silica. Physical Chemistry Chemical Physics.

Kihara, K. (1990). An X-ray study of the temperature dependence of the quartz structure. European Journal of Mineralogy, 2, 63-77.

Krummenacher, D., Merrihue, C. M., Pepin, R. O., \& Reynolds, J. H. (1962). Meteoritic bypton and barium versus the general isotopic anomalies in meteoritic xenon. Geochimica et Cosmochimica Acta, 28, 231-249.

Larson A.C., \& von Dreele, R.B. (2000). General structure analysis system (GSAS). Los Alamos National Report 86-748.

Lee, K. M., \& Steinle-Neumann, G. (2006). High-pressure alloying of iron and xenon: "Missing” Xe in the Earth's core? Journal of Geophysical Research, 111, B02202. https://doi.org/10.1029/2005JB003781c

Marrocchi, Y., \& Marty, B. (2013). Experimental determination of the xenon isotopic fractionation during adsorption. Geophysical Research Letters, 40, 4165-4170. https://doi.org/10.1002/grl.50845

Matsuda, J.-i., \& Matsubara, K. (1989). Noble gases in silica and their implication for the terrestrial "missing" Xe. Geophysical Research Letters, 16(1), 81-84. https://doi.org/10.1029/GL016i001p00081

Méheut, M. (2008). Calcul prédictif du facteur de partage isotopique entre minéraux dans le cadre de la théorie de la fonctionnelle de la densité - TEL (thèseshttps://tel.archives-ouvertes.fr/tel-00231076/document).

Pepin, R. O. (1991). On the origin and early evolution of terrestrial planet atmospheres and meteoritic volatiles. Icarus, 92(1), 2-79. https:// doi.org/10.1016/0019-1035(91)90036-S

Perdew, J. P., Burke, K., \& Ernzerhof, M. (1996). Generalized gradient approximation made simple. Physical Review Letters, 77(18), $16,533-16,539$

Prescher, C., \& Prakapenka, V. B. (2015). DIOPTAS: A program for reduction of two-dimensional X-ray diffraction data and data exploration. High Pressure Research: An International Journal, 35(3), 223-230.

Probert, M. I. J. (2010). An ab initio study of xenon retention in alpha-quartz. Journal of Physics: Condensed Matter, 22, 025501.

Pujol, M., Marty, B., \& Burgess, R. (2011). Chondritic-like xenon trapped in Archean rocks: A possible signature of the ancient atmosphere. Earth and Planetary Science Letters, 308, 298-306.

Ribas, I., Guinan, E. F., Güdel, M., \& Audard, M. (2005). Evolution of the solar activity over time and effects on planetary atmospheres. I. High-energy irradiances (1-1700 A). The Astrophysical Journal, 622(1), 680-694. https://doi.org/10.1086/427977

Sanloup, C., Schmidt, B. C., Gudfinnsson, G., Dewaele, A., \& Mezouar, M. (2011). Xenon and argon: A contrasting behavior in olivine at depth. Geochimica et Cosmochimica Acta, 75(21), 6271-6284. https://doi.org/10.1016/j.gca.2011.08.023

Sanloup, C., Hemley, R. J., \& Mao, H.-k. (2002). Evidence for xenon silicates at high pressure and temperature. Geophysical Research Letters, 29(18), 1883. https://doi.org/10.1029/2002GL014973

Sanloup, C., Schmidt, B. C., Perez, E. M. C., Jambon, A., Gregoryanz, E., \& Mezouar, M. (2005). Retention of xenon in quartz and Earth's missing xenon. Science, 310(5751), 1174-1177. https://doi.org/10.1126/science.1119070

Shoval, S., Champagnon, B., \& Panczer, G. (1997). The quartz-cristobalite transformation in heated chert rock composed of micro and crypto-quartz by Micro-Raman and FT-IR spectroscopy methods. Journal of Thermal Analysis, 50(1-2), 203-213. https://doi.org/ 10.1007/BF01979562 
Smyth, J. R., Holl, C. M., Langenhorst, F., Laustsen, H. M. S., Rossman, G. R., Kleppe, A., et al. (2005). Crystal chemistry of wadsleyite II and water in the Earth's interior. Physics and Chemistry of Minerals, 31(10), 691-705. https://doi.org/10.1007/s00269-004-0431-x

Smyth, J. R., \& Kawamoto, T. (1997). Wadsleyite II: A new high pressure hydrous phase in the peridotite-H2O system. Earth and Planetary Science Letters, 146(1-2), E9-E16. https://doi.org/10.1016/S0012-821X(96)00230-0

Stavrou, E., Yao, Y., Goncharov, A. F., Lobanov, S. S., Zaug, J. M., Liu, H., et al. (2017). Synthesis of xenon and iron-nickel intermetallic compounds at Earth's core thermodynamic conditions. Physical Review Letters, 120(9).

Swindle, T. D. (2002). Martian Noble gases. Reviews in Mineralogy and Geochemistry, 47(1), 171-190. https://doi.org/10.2138/rmg.2002.47.6

Troullier, N., \& Martins, J. L. (1991). Efficient pseudopotentials for plane-wave calculations. Physical Review B, 43(3), 1993-2006. https:// doi.org/10.1103/PhysRevB.43.1993

Wang, J., Mao, Z., Jiang, F., \& Duffy, T. S. (2015). Elasticity of single-crystal quartz to $10 \mathrm{GPa}$. Physics and Chemistry of Minerals, 45, 203-212.

Williams, Q., Hemley, R. J., Kruger, M. B., \& Jeanloz, R. (1993). High-pressure infrared spectra of $\propto-$ Quartz, coesite, stishovite and silica glass. Journal of Geophysical Research, 98(B12), 22,157-22,170. https://doi.org/10.1029/93JB02171

Zhu, L., Liu, H., Pickard, C. J., Zou, G., \& Ma, Y. (2014). Reactions of xenon with iron and nickel are predicted in the Earth's inner core. Nature Chemistry, 6(7), 644-648. https://doi.org/10.1038/nchem.1925 